\title{
Delimiting the scope of the hinterland of ports: proposal and case study
}

\begin{abstract}
:
The purpose of this paper is to provide a tool to delimit the scope of the hinterland of ports as accurately and simply as possible. To achieve this goal, an adapted version of the Huff model is proposed. In order to verify the validity of the proposal, it was applied to the Spanish case. As repulsion and attraction factors, both key aspects in the Spatial Interaction Models, the province-port travel time along the road network and the container throughput of the ports were considered respectively. The estimated hinterland of the analysed container ports fits well the observed flows. The obtained results confirm that the proposed methodology allows to identify the scope of the hinterland of ports in an effective an easy way, which is of interest both to stakeholders and policy makers.
\end{abstract}

Keywords: export flows; inland traffic; hinterland; Huff model; ports; Spatial Interaction Models. 


\section{Introduction}

In general terms, the port hinterland is the geographical area where the port has the substantial part of its business (that is, where the bulk of its traffic is generated) (Notteboom, 2008), and also the zone mainly served by that port (Guerrero, 2014). Traditionally, the hinterlands were concentrated around the port facilities because the proximity of ports to the production/consumption centres was key for their choice. Nevertheless, the situation has changed owing to the dematerialization and containerization process of the transport flows (Fleming and Hayuth, 1994) ${ }^{1}$. Traffic flows now have large volatility due to the progress of physical and organizational connectivity of the transportation system. That volatility means that the average distance covered by cargo has increased significantly, allowing both the overlap of the hinterlands and their discontinuous spatial expansion through inland islands developed around inland terminals $^{2}$. Furthermore, the port-hinterland relationship has a renewed interest both because inland transport costs constitute a significant fraction of logistics costs and most bottlenecks take place in the hinterland ${ }^{3}$ (van Der Horst and De Langen, 2008). Consequently, the analysis of this topic is relevant as it contributes to identify where and how the land transport infrastructure needs to be improved.

As Notteboom (2008) and Notteboom and Rodrigue (2005) state, drawing the port hinterland bearing in mind this new reality is not a simple task ${ }^{4}$, but the understanding of the underlying process has an increasing interest because it contributes to uncover the dynamics of the inland distribution of the maritime flows (which channel the bulk of international trade). This is a convenient first step for stakeholders and policy makers involved in decision making regarding both the design of port strategies and the map of infrastructures. For the former, it is possible to have a clearer understanding of the actual

1 These authors were pioneers in recognising the relevance of the hinterland in the port activity despite the process of containerization.

2 Notteboomand Rodrigue (2005) developed the concept of port regionalization to explain this new reality. See Rodrigue and Notteboom (2006) for a deeper understanding of this concept, and Santos and Soares (2017) for a literature review on articles based on the port regionalization process.

3 See van Der Horst and De Langen (2008) for a review of the main challenges regarding the coordination problems in hinterland transport chains.

4 Notteboom and Rodrigue (2007) point out that hinterlands are a complex spatial and functional structure resulting from the mixture of three components, namely the macro-economic, physical and logistical components. 
closest competitors regarding new targets, to discover potential customers in undeveloped markets regarding the port capabilities and, consequently, to reach them in terms of accessibility enhancement and/or services improvement offered by port facilities. For the latter, this additional knowledge allows them to take optimal decisions from the perspective of both the regional development and the budget constraints. In that sense, $\mathrm{Ng}$ et al. (2014) and Santos and Soares (2017) suggest as possible suitable initiatives for port regionalization the setting-up of a network of inland terminals, the planning of rail services or the improvement of large intermodal corridor efficiency.

The scope of the hinterland of ports is directly linked to the ability of ports to attract traffic, since both the origin and the final destination of the maritime flows are on the inland side (Garcia-Alonso et al, 2016). That means that the hinterland configuration depends on the success of the corresponding port when competing for the traffic on the landside ${ }^{5}$ and, consequently, both aspects can be seen as two sides of the same coin. This is why the topic of port hinterlands has been analysed from the perspective of the Discrete Choice Theory (see, for instance, Garcia-Alonso and Sanchez-Soriano, 2009). However, this paper proposes an alternative approach.

The goal of this paper is to propose a methodology to delimit the hinterland of ports as accurately and simply as possible. The underlying hypothesis is that the scope of the hinterlands can be drawn simply taking into account the location of the ports and their throughput. The proposal is to adapt the Huff model, including as explicative variables the province-port travel time and the port container throughput. This adapted version was applied to a case study in order to verify the stated hypothesis and the effectiveness of the proposed model. Specifically, it was implemented to draw the hinterland of a set of Spanish container ports regarding the national export flows in 2012 (the last year with all data available).

Spain is a natural gateway between Europe and both North Africa and Latin America. Nevertheless, the country is a peripheral region in South-Western Europe. In general terms, the Mediterranean ports are heavily penalized for their distance from areas with high population and economic densities (Chapelon, 2006). Additionally, the Spanish ports face a major challenge due to technical difficulties in rail shuttles (Notteboom, 2010). Therefore, the disconnection between the nationality of the gateway and the

5 In the same way, the quality of hinterland connections has become a relevant key aspect for the port choice (Ferrari et al., 2011; Nazemzadeh and Vanelslander, 2015; Ng et al., 2014). 
hinterland observed in Europe (Rodrigue and Notteboom, 2010a) is particularly hard in the Spanish case ${ }^{6}$. However, Notteboom (2008) points out that investments made have led to an increase in the trade flows, benefiting Southern Spain and Northern Italy. Furthermore, Bensassi et al. (2015) state that the advantages of the geographical location of Spain will outweigh the disadvantages once proper logistics improvement has been carried out.

The Spanish ports whose hinterland was analysed are Barcelona, Bilbao and Valencia. It is worth noting that the triangular area delimited by these three ports (making up a contestable hinterland for them) is the core of the Spanish Peninsular economy (including Madrid). Additionally, these ports have been chosen for the analysis because they are the major peninsular ports of the country, together with Algeciras. However, Algeciras was removed from the analysis because it is specialised in transhipment traffic and, consequently, the traffic coming from its hinterland is much less relevant. The port of Bilbao, located on the north coast, is specialised in short-sea and feeder traffic from the northern range ports of Europe, whereas the ports of Valencia and Barcelona, both located on the east coast, are the two major ports for Spanish deep-sea cargo (Monios, 2011). In 2012, the ports of Barcelona, Bilbao and Valencia carried respectively 11, 4 and $32 \%$ of the total container traffic in Spain.

The remainder of the paper is organized as follows. Section 2 presents the review of literature concerning the study of the hinterland of ports from the spatial perspective. The proposed methodology, its extensions and the data sources are shown in Sections 3 and 4. The obtained results are provided in Section 5. Section 6 proposes a discussion from the results. Finally, Section 7 summarises the main conclusions and proposes further research in this field.

\section{Literature review on port hinterland analysis from the spatial perspective}

Both the port competitiveness and the port choice are two topics that have been greatly analysed. Nevertheless, the spatial consequences of both aspects are much scarcer

6 There is a recent article analysing the Portuguese ports and their capture of hinterlands in Spain (see Santos and Soares, 2017). Nevertheless, the maritime traffic generated within those Spanish regions is negligible compared with the total amount of the Spanish traffic, geographically concentrated along the Mediterranean corridor, the North-Eastern corner and Madrid. 
in the literature (see Martínez Moya and Feo Valero, 2016; Woo et al., 2011). Malchow and Kanafani (2001) were pioneers in analysing the port choice process from the perspective of the Discrete Choice Theory. They applied a Multinomial Logit Model (MLM) with disaggregated data to analyse the distribution of maritime shipments among US ports. Since then, many authors have used different MLM to study the inter-port traffic distribution from the maritime side, but also from the land perspective. However, other approaches have also been used. Specifically, geographers have developed numerous models to analyse the spatial evolution of nodes and corridors linked to ports and port systems (see $\mathrm{Ng}, 2013$; Wilmsmeier et al., 2014). Nevertheless, empirical research based on the theoretical foundations of the spatial econometric analysis is scarce.

Regarding the analysis of the specific Spanish case, some articles can be found about the port hinterland topic. Their main conclusions are: i) the province-port distance remains a key variable for the port choice (Garcia-Alonso and Sanchez-Soriano, 2009); ii) the hinterland of the Spanish container ports depends mainly on the traffic generated in nearby provinces (Garcia-Alonso and Sanchez-Soriano, 2010); iii) the impact of land transport costs is slightly higher than that of maritime transport (Veldman et al., 2011); and finally iv) the hinterland of the Valencia port was expanded to a greater extent during the last decade (Garcia-Alonso et al., 2016). This last paper indicates that a spatial interaction approach can help to properly analyse the evolution of the hinterland of ports.

To the best of our knowledge, during the last decade only four relevant articles have been published focusing on the distribution of the maritime flows from the perspective of the Spatial Interaction Models (SIM). The articles in question are: Debrie and Guerrero (2008), Ferrari et al. (2011), Guerrero (2014) and Zhuang and Yu (2014). In their article Debrie and Guerrero (2008) use a doubly constrained model in order to verify whether distance remains relevant in determining the hinterland of the French ports. They apply the Euclidean distance between the French departments and ports. Ferrari et al. (2011) use maximizing entropy models (production and doubly constrained) to analyse the container traffic regarding the Ligurian ports (in Italy). They also employ the Euclidean distance, but they innovate when considering the most populated cities of inland Italy as centroids. Guerrero (2014), analysing again the French case with a doubly constrained model, concludes that distance is an important indicator of port flows, and detects that major ports serve more destinations and have better connections with their hinterland. He uses truck travel time instead of Euclidean distance. Finally, Zhuang and Yu (2014) propose an adapted Huff model and the use of the ArcGIS tool to map the hinterland of 
the Shanghai and Ningbo ports. The variables applied were container throughput and distance through the road network.

Debrie and Guerrero (2008), Ferrari et al. (2011) and Guerrero (2014) only analyse the role of the distance in the inland distribution process of the maritime flows. On the other hand, Zhuang and Yu (2014) map the hinterland of the analysed ports, but they do not estimate the parameters of the attractiveness and distance; they just incorporate their standard values ( 1 and -2 , respectively). That could lead to misleading results as they lack their statistical significance. The aim of this paper is to fill these gaps, taking as a starting point the main contributions of the previously mentioned articles.

In order to go a step further, an adapted version of the Huff model is proposed. This version includes the travel time (repulsion factor) and the container throughput (attractiveness factor) as explicative variables (in line with Zhuang and $\mathrm{Yu}, 2014$ ), but estimating their corresponding parameters in order to give accuracy and robustness to the model (in line with Debrie and Guerrero, 2008; Ferrari et al., 2011; Guerrero, 2014). How the model has been adapted and how the variables have been estimated are questions to be explained in the following section.

\section{Methodological proposal}

As stated above, the theoretical foundation of many proposed models is the Discrete Choice Theory. The Multinomial Logit Models (MLM) are the simplest and most commonly applied. They use an explicative-stochastic perspective and revealed preferences, as do the SIM, but their theoretical approaches are different ${ }^{7}$ and such theoretical distinctions are relevant. Firstly, the SIM are more suitable when using aggregated data since these models have less initial assumptions than models based on individual choices (Roy, 2004). Additionally, as Kerkman et al. (2017, p. 155) highlight: "The advantage of spatial interaction models is that these models can take into account the influence of both spatial characteristics and characteristics of the transport network simultaneously". Merkel (2017) also provides an additional argument supporting that theoretical approach: as ports have a spatially fixed location, the distance separating them influences how intense their relationships of competition/complementarity are; that is, the

\footnotetext{
${ }^{7}$ Anas (1983) provides a theoretical comparis on between both methods.
} 
unobservable effects concerning the degree of interdependence between a set of ports can be approximated by distance.

The location of ports is a variable often considered when analysing the port choice process though its role is usually controversial (Tongzon, 2009). Many authors consider that port selection is not necessarily related to the inland distance, although others highlight that distance remains a powerful explanatory variable in defining port hinterlands (Ferrari et al., 2011). For instance, $\mathrm{Ng}$ et al. (2014) and Rodrigue and Notteboom (2010) point out the relevance of the territorial and economic characteristics of the immediate geographical region for ports and their connections with their corresponding hinterlands. More recently, Shi and Li (2016) even state that the impact of the regional economy on the hinterland development of the ports is increasingly significant. Nevertheless, distance is being replaced by time when assessing the transportation costs (Hesse and Rodrigue, 2004). As Rodrigue (2012) states, technology and infrastructure improvements make the friction of distance change over time. Consequently, travel time is usually considered nowadays as the main impedance variable (Kerkman et al., 2017).

\subsection{The Huff model}

The Spatial Interaction Models are often proposed in the Regional Science field. The central idea of SIM comes from the Gravitational Models, so named by analogy to Newton's concept of gravity. The first researcher that applied this concept of gravity to measure an influence area was Reilly (1929). He developed a model to identify geographically commercial areas of two cities in an intermediate region, named Law of Retail Gravitation (Roy, 2004). Of all the alternatives developed later within the SIM field (and referring to the analysis of trade area), this paper proposes an adapted version of the Huff model as a tool to delimit the scope of the hinterland of ports.

The Huff model was proposed to estimate the area of influence of shopping centres. Nevertheless, the applicability of that model to a wide range of problems and its relative ease of use justify its longevity (Huff, 2003). The goal of this model is to study the patterns of customer choice based on a hierarchical and behavioural process. It measures (in terms of probability) the attractiveness of a specific destination, $j$, for a customer located at a particular origin, $i$, regarding alternative destinations, $n$ (Huff, 1963, 1964). The model incorporates two variables, both linked to the destination: one concerning the 
attraction force (mass) and one regarding the repulsion force (friction). Mathematically, it was originally formulated as (1):

$$
P\left(C_{i j}\right)=\frac{s_{j}}{T_{i j}^{\lambda}} / \sum_{j=1}^{n}\left(\frac{s_{j}}{T_{i j}^{\lambda}}\right)
$$

where

$P\left(C_{i j}\right)=$ the probability that a customer at origin $i$ chooses the shopping centre $j$;

$S_{j}=$ the square footage of the space devoted to the sale of a specific merchandise at the shopping centre $j$;

$T_{i j}=$ the travel time to reach the shopping centre $j$ from the origin $i$, (obtained from customer surveys);

$\lambda=$ the parameter measuring the customers' sensibility to $T_{i j}$.

The Huff model presents some remarkable features making it an interesting alternative to delimit the hinterland of ports. Firstly, the radial format of the borders of the areas of influence; that is, a curved series with probability levels and overlaps. Secondly, the travel time is used as explicative variable instead of the straight-line distance, which makes the analysis much more realistic. Thirdly, the distance decay parameter can be estimated, since it can vary depending on the context (however, it is usually considered constant and equal to -2). Finally, the spatial behaviour of the customer is assumed to be in line with the opportunity cost concept. Specifically, Huff (1963) highlighted that when a customer faces a set of alternatives, the probability of a particular one being chosen is directly proportional to the perceived advantages obtained from that alternative, which enables to estimate demand surface probabilities. Finally, Huff (2003) highlights the interest of estimating the parameters of both variables (the distance decay and the attractiveness), since the customer knows the services and structure of destinations before travelling.

\subsection{The adapted version of the Huff model}

The original Huff model analyses flows of customers to retail locations, whereas the aim of this paper is to analyse export flows towards port facilities. Though they are different tasks, there is a shipper behind each cargo choosing from among all the possible destinations. Therefore, the changes to the original model only affect the attractive ness and repulsion variables linked to the destination; i.e., to the ports.

Huff (1963) considered the size of the shopping centres to be the attractiveness factor, and the travel time separating them from customers the repulsion factor. In the 
port selection field, many variables can be considered determinant, but their relevance varies with the analysis approach (see, for instance, $\mathrm{Ng}$, 2006; Sanchez et al., 2011). In this article, the container throughput is considered a proxy of the port attractiveness, and the province-port travel time is introduced as a proxy of the repulsion factors. Therefore, the adapted model is expressed as (2):

$$
P\left(C_{i j}\right)=\frac{\operatorname{Cont}_{j}^{\gamma}}{T_{i j}^{\lambda}} / \sum_{j=1}^{n}\left(\frac{\operatorname{Cont}_{j}^{\gamma}}{T_{i j}^{\lambda}}\right)
$$

Where:

$P\left(C_{i j}\right)=$ the probability that a shipper at province $i$ chooses port $j$;

Cont $_{j}=$ the container throughput of port $j$;

$\gamma=$ the parameter measuring the shippers' sensibility to Cont;

$T_{i j}=$ the travel time from $i$ (province centroid) to port $j$;

$\lambda=$ the parameter measuring the shippers' sensibility to $T_{i j}$.

\subsection{Parameter estimation}

The parameters $\gamma$ and $\lambda$ were estimated to be included in the adapted Huff model. Their estimation took place through a SIM constrained in the origin (or productionconstrained model), following Flowerdew and Aitkin (1982). These authors point out that when the mean of the dependent variable (analysed as a result of a discrete probability process) is a function of the independent variables, a Poisson-distributed model can be used. In that case, the Iteratively Reweighting Least Squares (IWSL) method is recommended to find the maximum likelihood of the equation. It allows successive iterations until the value of the estimated parameters leads to converge.

Applied to the case study, the dependence of the outflow from provinces $i$ to port $j$ $(\theta i j)$ with the port's container throughput $($ Contj) and province - port travel time (Tij) is expressed through (3):

$$
\theta_{i j}=\exp \left(\beta_{0}+\mu_{i}+\gamma \ln \operatorname{Cont}_{j}+\lambda \ln T_{i j}\right)
$$

Where:

$\beta_{0}=$ the constant;

$\mu_{i}=$ dummies for the origins, $i$.

From (3), the IWSL method provides the maximum likelihood estimation for the parameters $(\gamma, \lambda)$. 
In a Poisson distribution, the variance of the observations is equal to the mean. This is a very restrictive assumption. From one side, the population heterogeneity can cause high-leverage points (outliers) (Baxter, 1985; Zeileis, 2004). From the other side, each flow usually involves more than one individual (Flowerdew and Aitkin, 1982). Both circumstances take place in the maritime traffic distribution process: there are many stakeholders (with different goals) involved and the volume of traffic varies with each shipment. Therefore, the variance can overcome the mean. In those cases, although the parameters resulting from a Poisson distribution are consistent, their standard errors deserve attention because their estimation, their statistical tests and, consequently, the overall goodness-of-fit of the model may be distorted (see Baxter, 1985; Cameron and Trivedi, 1998; Flowerdew and Aitkin, 1982).

Once the parameters are obtained by means of the SIM, they are included in the Huff model, as shown in (2). After that, it is possible to map the potential hinterland of ports by drawing lines connecting all the statistical units by means of the Market Analysis Tool for the Huff model incorporated in ArcGIS.

\section{Data sources}

For this particular case study, the 47 Spanish peninsular provinces (origins, $i$ ) and the ports of Barcelona, Bilbao and Valencia (destinations, $j$ ) are considered. The analyzed flows are the Spanish exports channeled by container to America and Asia in $2012^{8}$ - the last year with data available about the status of the road network from Stelder et al. (2013). Figure 1 shows the location of the ports and the provincial share in export flow generation (in tonnes) to the considered destinations. As can be seen in the figure, and was stated above, the Mediterranean corridor, the North-Eastern corner and Madrid accounted for $94 \%$ of traffic generation.

\footnotetext{
${ }^{8}$ In order to avoid possible mistakes regarding the main transport mode registered at the data source, only the American and Asiatic countries were considered as destination. On the otherhand, the huge amount of data generated per year makes it hard to analyse a longer period. That makes sense when the goal is to study the evolution of the hinterlands, but it is not necessary when it is intended to check the potential of the proposed model to identify their scope. Additionally, import flows were not added because in such a case the proposed origin-constrained model should be replaced by a double constrained one.
} 

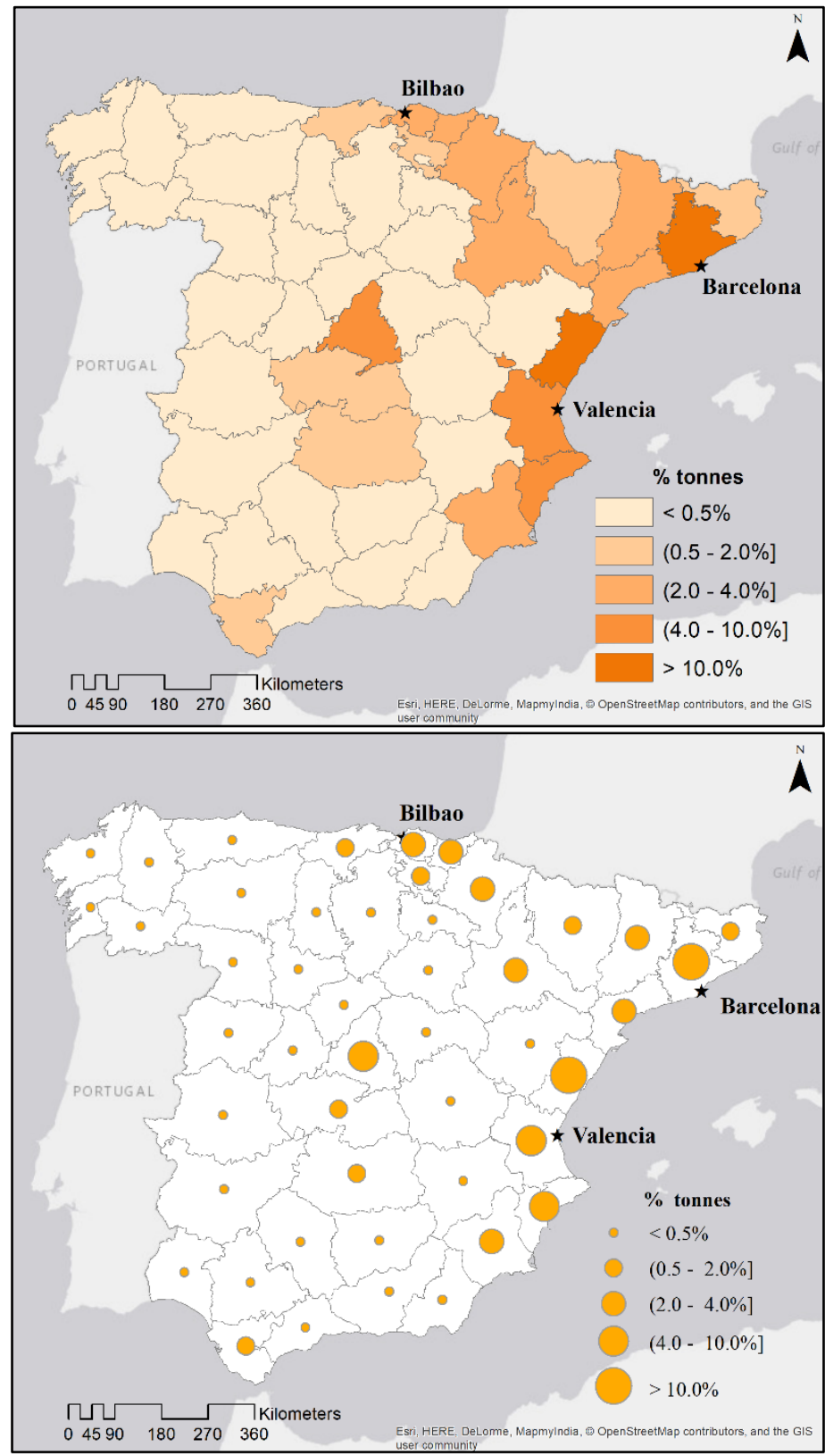

Fig. 1 Provincial share in export flows generation (in tonnes)

to Asia and America (2012).

Source: based on Agencia Estatal de Administración Tributaria de España. Colours: ColorBrewer.

The outflows were obtained from the Agencia Estatal de Administración Tributaria de España. The data source is freely available and provides information about the composition and volume (in Euros and tonnes) of flows, the country of origin/destination and the provincial origin/destination of the Spanish foreign trade by mode of transport over time. It also provides information about the Customs office managing the flow, thus the port chosen can be indirectly identified. Obviously, that source of data only provides information about the Spanish foreign trade. That means that the traffic generated outside the Spanish borders was ignored, despite the fact that the ports' hinterland can transcend 
national boundaries. The main reason is the lack of traffic data from France and Portugal. However, this fact should not affect the conclusions drawn because the bulk of the traffic of the Spanish ports comes from Spanish trade (and vice versa: the bulk of the Spanish foreign trade is channelled through the Spanish ports).

On the other hand, the container throughput was provided by the Ente Público Puertos del Estado. The province-port travel time was obtained from the European road network $^{9}$ for 2012 (Stelder, 2016). The fastest path (by road) through the real network has been obtained from the Network Analyst Extension tool of ArcGIS. Finally, the data sources corresponding to the variables used in ArcGIS are summarised in Table 1. All these data are also open access.

Table 1. Sources of data used in the ArcGIS tool

\begin{tabular}{l|ll}
\hline \multicolumn{1}{c|}{ Data } & \multicolumn{1}{|c}{ Type } & \multicolumn{1}{c}{ Source } \\
\hline Ports & Points & GISCO Ports 2013 dataset (European Commission, 2014) \\
Provinces & Polygons & NUTS 2013 dataset (European Commission, 2014) \\
Province capital & Points & NUTS 2013 dataset (European Commission, 2014) \\
\hline
\end{tabular}

\section{Results}

The results were obtained following two steps. Firstly, the parameters of attractiveness $(\gamma)$ and repulsion $(\lambda)$ were estimated by a production-constrained model using a Poisson distribution, as explained above. Secondly, the estimated parameters were incorporated into the proposed Huff model in order to delimit the scope of the hinterland of the analysed ports.

The results corresponding to the first step are displayed in Table 2. To assess a model performance, the likelihood ratio, the Akaike Information Criterion (AIC) and the residual deviance are frequently used. Nevertheless, they can be miscalculated when data are over dispersed, as is the case. To avoid that problem, a robust covariance matrix to standard errors was calculated (Zeileis, 2004, 2006). The coefficient of determination associated with the correlation of observed against predicted flows $\left(\mathrm{R}^{2}\right)$ was also

\footnotetext{
${ }^{9}$ The railway transport was not considered because it was $6 \%$ of the traffic that used roads to travel to and from the Spanish ports in 2012. That is because the Spanish inland distances do not afford rail a natural advantage.
} 
accounted (Dennett, 2012; Stillwell, 2005). As can be seen hereafter, the results are robust and the estimation of both parameters is significant according to both methods.

Table 2. Results of the parameter estimation

\begin{tabular}{|l|c|c|c|c|}
\hline Parameters & Results & $\begin{array}{c}\text { Standard } \\
\text { Errors }\end{array}$ & $\begin{array}{c}\text { Robust Standard } \\
\text { Errors }\end{array}$ & \multirow{2}{*}{$\boldsymbol{R}^{\mathbf{2}}$} \\
\hline Container throughput $(\gamma)$ & $0.69 * * *$ & 0.0007 & 0.1140 & \multirow{2}{*}{$97.85 \%$} \\
\hline Travel time $(\lambda)$ & $-1.48 * * *$ & 0.0006 & 0.2639 & \\
\hline$* * *$ Significant in 0.01 &
\end{tabular}

The sign of the parameters is as expected: negative for the travel time and positive for the container throughput. Therefore, the former variable acts as a repulsion factor, whereas the second favours the hinterland expansion. The obtained values of the parameters allow to fit the observed outflows from provinces to ports with $97.85 \%$ accuracy. However, the explanatory power of the considered variables differs considerably ${ }^{10}$ : the impact of the travel time variable greatly surpasses the impact of the container throughput. A similar value for the distance decay parameter was obtained by Ferrari et al. (2011) for the hinterland of the Ligurian ports (-1.38). That result is in line with Parola et al. (2016), who point out that shippers tend to consider "port location" and "hinterland connections" as the most important factors in port choice. Unfortunately, the parameter of the attractiveness variable cannot be compared with previous estimates because we are not aware of studies measuring it with a similar methodology.

Once obtained, the parameters were included in the adapted version of the Huff model. This second step allows us to delimit the probabilistic scope of the hinterland of the ports, which is the goal of this article. The corresponding results are summarized in Table 3 and illustrated in Figure 2.

As can be seen, the model fits well the observed flows by port, and only small discrepancies exist between those and the estimated flows. Specifically, the real flow of the port of Barcelona surpasses the estimated $1.1 \%$, whereas those of the ports of Bilbao and Valencia are overestimated $0.7 \%$ and $0.4 \%$ respectively. These outcomes mean that the relationship provinces-Barcelona port is stronger than expected, but it is slightly weaker regarding the ports of Bilbao and Valencia.

\footnotetext{
${ }^{10}$ When a Poisson regression is handled, the coefficients should be interpreted as a percentage change in the dependent variable (Wooldridge, 2009).
} 
Table 3. Real vs Estimated market share (2012)

\begin{tabular}{lllc}
\hline Ports & Real & Estimated & Difference (Real-Estimated) \\
\hline Barcelona & $35.7 \%$ & $34.6 \%$ & $1.1 \%$ \\
Bilbao & $10.9 \%$ & $11.7 \%$ & $-0.7 \%$ \\
Valencia & $53.4 \%$ & $53.8 \%$ & $-0.4 \%$ \\
\hline
\end{tabular}

The maps in Figure 2 show the probabilistic scope for the hinterland of the ports allowing their overlap. They are drawn by means of a Kriging process to interpolate both the observed and the estimated flows through ArcGIS. Visually, the maps for the real and the estimated flows show very similar hinterlands (regarding size and intensity), although small differences exist between them, as presented in Table 3. Therefore, additional factors other than the explicative variables considered here should be taken into account, although that is beyond the scope of this study ${ }^{11}$.

The maps in Figure 2 confirm the importance of the local hinterland, as Notteboom (2010) observes for the major European ports. He also states that Western Mediterranean gateway ports have improved their connectivity and, consequently, they benefit from economies of scale resulting from a higher volume of traffic. These economies of scale are linked to larger vessels and the geographical concentration of logistics companies. Maybe these factors, key for the success of the Northern European ports in the regionalization process, could also explain the success of the Spanish Mediterranean ports with respect to Bilbao. Furthermore, Oliveira and Cariou (2015) point out that ports with large market shares are usually more efficient. That could be the case of the port of Valencia. As stated above, that port carries much more container traffic and is less dependent on its immediate surrounding hinterland; that is, its relevant hinterland is much more expanded. The same argument, but in the opposite way, could also be applied to the port of Bilbao: its market share is by far the smallest and its hinterland is the most overestimated. However, once again, that discussion is outside the scope of this study.

\footnotetext{
11 For instance, the quality of hinterland accessibility of a port is a key factor. The increasing logistical pressure concerns not only the infrastructure, but also the efficiency in freight distribution strategies (Rodrigue and Notteboom, 2010a). Van Der Horst and De Langen (2008) state that accessibility depends on factors as variable as the behaviour of the terminal operators, freight forwarders, container operators or the port authority. Furthermore, Rodrigue and Notteboom(2010b) point out that the hinterland borders also depend on the characteristics of the foreland.
} 


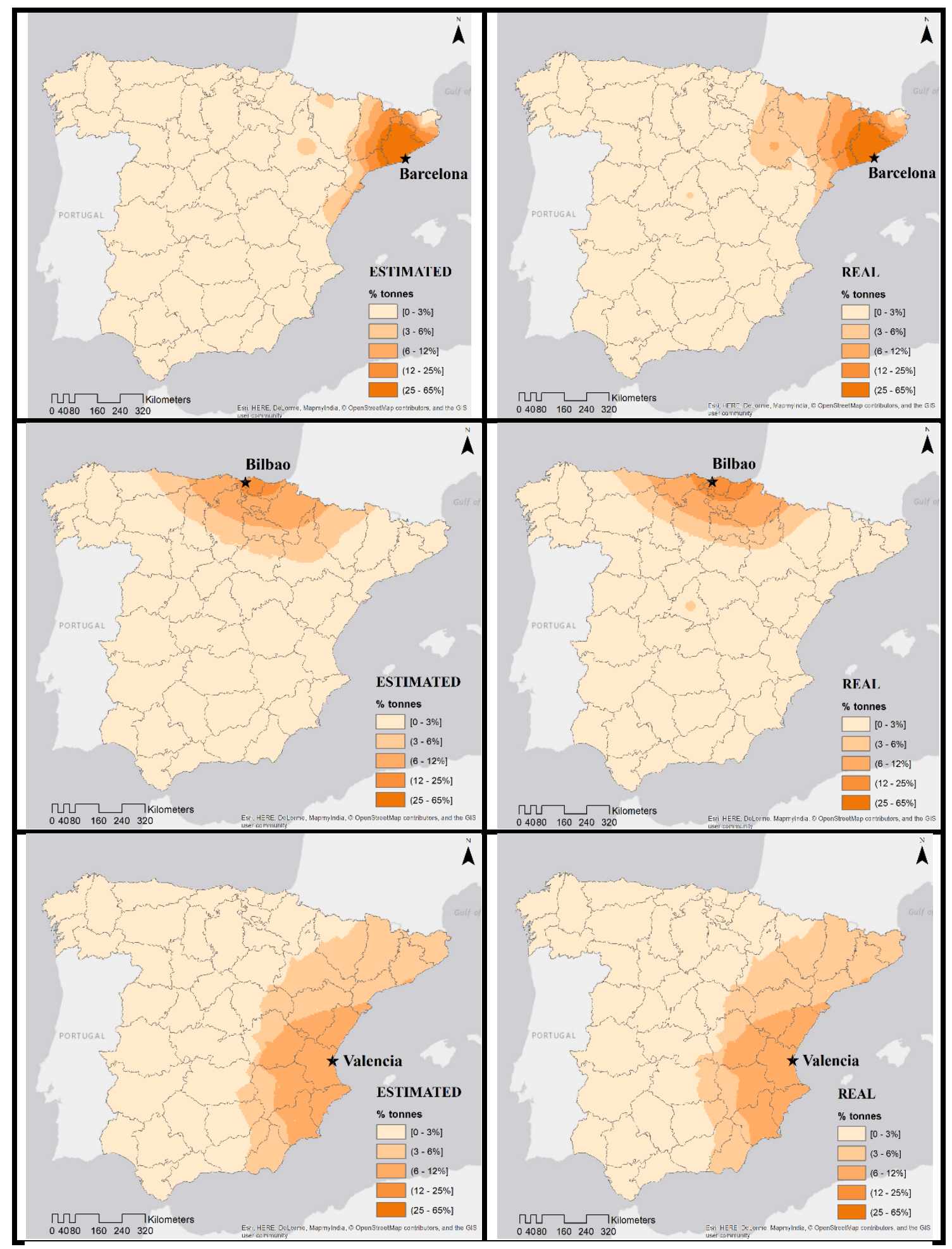

Figure 2. Estimation surface for real and estimated port hinterlands, in percentage of tonnes (2012).

Source: based on Agencia Estatal de Administración Tributaria de España and model results. Colours: ColorBrewer.

To provide a more accurate picture of the discrepancies between the real and the estimated flows, the port perspective must be replaced by the provincial perspective. 
Figure 3 shows the maps with the corresponding deviations by province (real flows minus estimated). In general terms they are negligible, confirming once again the robustness of the results. The biggest mismatches are linked to the port of Barcelona: provinces 4 (Lleida, 4.6\%), 5 (Barcelona, -5.5\%) and 7 (Castellón, -4.1\%). Bilbao is the port with the highest number of provincial discrepancies over $0.1 \%$, although they are majorly under $1 \%$. Finally, the provincial mismatches regarding the port of Valencia are minor, both in number and value. They only surpass $2 \%$ for provinces 4 (Lleida, $-2.6 \%$ ), 5 (Barcelona, 2.8\%) and 7 (Castellón, 3\%). These 3 provinces are among those generating the greatest amount of flows in Spain. However, the most remarkable fact is that the greatest mismatches are found in the provinces conforming the contestable area for the three analysed ports. Taking into account the sign of the discrepancies, it is particularly interesting to pay attention to provinces 2 (Zaragoza), 3 (Huesca) and 4 (Lleida), where the real flows of the port of Barcelona surpass the estimated, and the ports of Bilbao and Valencia are in the opposite situation. It is convenient to highlight here that TMZ, the main Spanish inland terminal is located in Zaragoza (province 2), and more than $90 \%$ of its container traffic is linked to the port of Barcelona (Garcia-Alonso et al., 2017; Monios, 2011). The flow overestimation of the provinces of Barcelona and Bilbao with respect to their own ports also deserve attention. The destination of flows is probably key in these cases. In Figure 3 we can see that the flows of Barcelona (5) are particularly underestimated for the port of Bilbao. There it also can be seen that the mismatches for the flows generated in the province of Bilbao are negligible for the ports of Barcelona and Valencia.

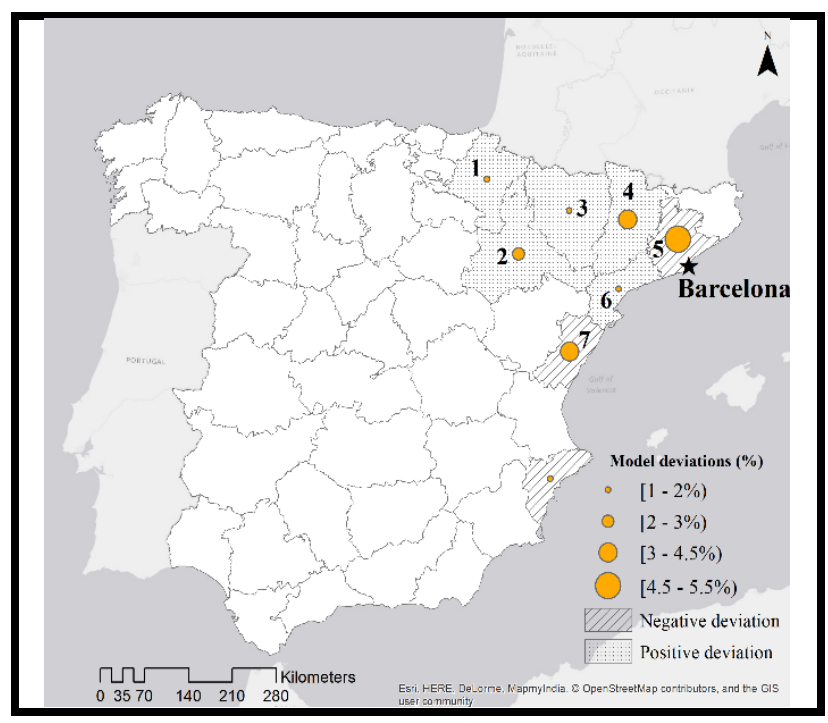




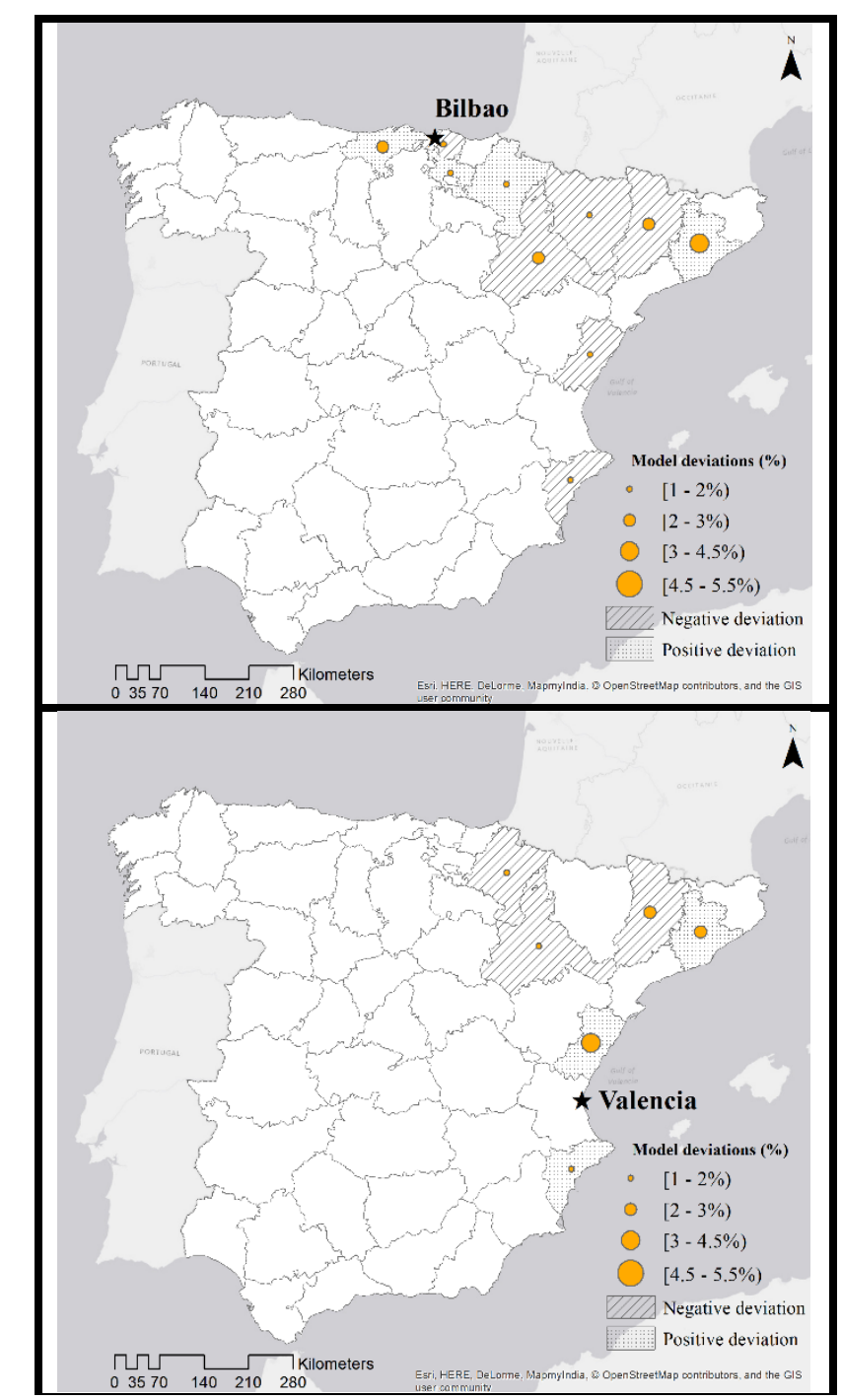

Figure 3. Model deviations by province in terms of tonnes (2012).

Source: based on Agencia Estatal de Administración Tributaria de España and model results. Colours: ColorBrewer.

\section{Discussion}

Reinforcing the knowledge on freight distribution patterns helps policymakers design a more efficient transport strategy, both at regional, national and supranational level. Also, delving deeper into the comprehension of the key factors of inter-port traffic distribution helps shippers and Port Authorities articulate their competitive strategies. Therefore, the more we know about how the hinterlands of the ports are configured, the better the decisions will be made.

This paper contributes to reinforce the existing knowledge on this topic. The proposed methodology not only allows to obtain an accurate picture about the maritime traffic distribution on the inland side, it also contributes to the debate due to the particular 
characteristics of the case study carried out. The obtained results highlight that it is necessary to face a difficult question about the infrastructure planning: the trade-off between efficiency and the territorial cohesion. That is, what to do when traffic generation is geographically so concentrated as it is in the Spanish case?

An efficient transport network must alleviate bottlenecks and complement missing links, reinforcing the competitive opportunities of the best positioned ports (Bensassi et al., 2015). As Márquez-Ramos et al. (2011, p. 573) state: "Although concentrating investments in a few ports and promoting their role as import/export gateways may be difficult from a political point of view in large countries with many kilometres of coast, as is the case in Spain, investing in several small or medium sized ports all aiming at the same container segment of the market may not be a strategy that leads to increasing the competitiveness of the country's exports”. Additionally, Márquez-Ramos (2016) concludes that port investment generates important spillovers for the neighbouring regions. She highlights that the more efficient a port, the greater the regional spillovers, giving as an example the wide indirect effect of the port of Valencia (confirmed here in Figure 2). Therefore, these effects should be considered when planning port investment, as concentrating the improvement in more efficient ports maximises the investment return. This is in line with the Trans-European Transport Network (TEN-T), which aims to connect the Iberian Peninsula to the rest of Europe through the Mediterranean Corridor, but not through a Northern axis. That initiative will probably favour the isolation of the median Spanish ports, located on the Northern coast, and hinder the export capability of their neighbouring regions. Should, therefore, an additional corridor be incorporated to link those ports/regions to the European core although their traffic generation does not currently justify the investment? But what will the future be of those ports/regions without such investment?

\section{Concluding remarks}

This paper provides valuable academic and practical insight. It contributes to the literature by adapting a Spatial Interaction Model to the analysis of the hinterland of ports. The obtained empirical results confirm the stated hypothesis: it is possible to draw the scope of the hinterlands taking into account only the throughput and location of the ports. Therefore, the goal of the paper is achieved: to propose a suitable methodology to delimit the scope of the hinterland of ports in a simple and accurate way. Simple, as the 
explicative variables are usually available; accurate, as their parameters can be estimated for each case study.

The throughput and port location represent the attraction and repulsion forces supporting the spatial models. This is of special interest due to the usual scarcity of data regarding both efficiency levels and port costs. From this paper we know that the throughput of the ports works as a proxy of their attractiveness in the adapted version of the Huff model. We also know that the friction of the distance varies with the inland infrastructure improvements, although the port location is fixed. Therefore, travel time is a better proxy than distance for repulsion forces. Furthermore, for instance, it allows to anticipate the evolution of the scope of the hinterlands resulting from a specific infrastructure improvement.

From this paper, we also now know that travel time contributes more than port throughput to explain the inter-port traffic distribution in the Spanish case. Therefore, it should be concluded that location is more relevant than the port throughput for the interport traffic distribution. However, it is possible that the geographical scope of the analysis modifies the results. Following previous papers analysing the success of Northern with respect to Mediterranean ports, it is expected that the greater the geographical scope of port competence (supranational vs national level), the smaller the impact of the inland proximity and the greater the relevance of alternative factors, such as connectivity or the quality of services.

The analysis of that subject is beyond the objective of this paper, but the proposed methodology makes it possible. Therefore, future research should address that question. Additionally, there are relevant factors that have not been considered and could reinforce the study. For instance, it would be interesting to analyse how the scope of the hinterland evolves over time, and also to identify how the relative relevance of the explicative variables varies with the type of cargo or regarding the quality of the inland infrastructure. That would be particularly interesting for both stakeholders and policymakers, respectively responsible for the traffic distribution and the infrastructure map design under budget restrictions. 


\section{References}

Agencia Estatal de Administración Tributaria de España [WWW Document], 2017. . Datos estadísticos [Online]. URL http://www.agenciatributaria.es (accessed 1.3.16).

Anas, A., 1983. Discrete Choice Theory, Information Theory and the Multinomial Logit and Gravity Models. Transp. Res. Part B Methodol. 17, 13-23. doi:10.1016/01912615(83)90023-1

Baxter, M.J., 1985. Quasi-likelihood estimation and diagnostic statistics for spatial interaction models. Environ. Plan. A 17, 1627-1635.

Bensassi, S., Márquez-Ramos, L., Martínez-Zarzoso, I., Suárez-Burguet, C., 2015. Relationship between logistics infrastructure and trade: Evidence from Spanish regional exports. Transp. Res. Part A Policy Pract. 72, 47-61. doi:10.1016/j.tra.2014.11.007

Cameron, A.C., Trivedi, P.K., 1998. Regression analysis of count data, Econometric Society Monographs No 30. Cambridge University Press. doi:10.2307/1271358

Chapelon, L., 2006. L'accessibilité, marqueur des inégalités de rayonnement des villes portuaires en Europa. Cybergeo Eur. J. Geogr. 345, 15.

ColorBrewer [WWW Document], n.d. URL http:/Www.colorbrewer.org (accessed 7.1.16).

Debrie, J., Guerrero, D., 2008. (Re)spatialiser la question portuaire : pour une lecture géographique des arrière-pays européens. L'esp. géographique 37, 45-56.

Dennett, A., 2012. Estimating flows between geographical locations:'get me started in'spatial interaction modelling. UCL Work. Pap. Ser. 44, 0-24.

Ente Público Puertos del Estado [WWW Document], 2017. . Anu. estadístico [Online]. URL http://www.puertos.es (accessed 7.3.17).

European Commission, 2014. GISCO dataset [WWW Document]. Geogr. Inf. Syst. Comm. doi:10.1007/s13398-014-0173-7.2

Ferrari, C., Parola, F., Gattorna, E., 2011. Measuring the quality of port hinterland accessibility: The Ligurian case. Transp. Policy 18, 382-391. doi:10.1016/j.tranpol.2010.11.002

Fleming, D.K., Hayuth, Y., 1994. Spatial characteristics of transportation hubs: centrality and intermediacy. J. Transp. Geogr. 2, 3-18.

Flowerdew, R., Aitkin, M., 1982. A method of fitting the gravity model based on the poisson distribution. J. Reg. Sci. 22, 191-202.

Garcia-Alonso, L., Martinez-Pardo, A., Vallejo-Pinto, J.Á., 2016. Analysis of the spatial development of the hinterland of ports: a case study. Int. J. Shipp. Transp. Logist. 8, 
Garcia-Alonso, L., Monios, J., Vallejo-Pinto, J.Á., 2017. Port competition through hinterland accessibility: the case of Spain. Marit. Econ. Logist. (in press).

Garcia-Alonso, L., Sanchez-Soriano, J., 2010. Analysis of the Evolution of the Inland Traffic Distribution and Provincial Hinterland Share of the Spanish Port System. Transp. Rev. 30, 275-297. doi:10.1080/01441640902985983

Garcia-Alonso, L., Sanchez-Soriano, J., 2009. Port selection from a hinterland perspective. Marit. Econ. Logist. 11, 260-269. doi:10.1057/mel.2009.9

Guerrero, D., 2014. Deep-sea hinterlands: Some empirical evidence of the spatial impact of containerization. J. Transp. Geogr. 35, 84-94. doi:10.1016/j.jtrangeo.2014.01.010

Hesse, M., Rodrigue, J.-P., 2004. The transport geography of logistic and freight distribution. J. Transp. Geogr. 12, 171-184. doi:10.1016/j.jtrangeo.2003.12.004

Huff, D.L., 2003. Parameter Estimation in the Huff Model. ArcUser 3.

Huff, D.L., 1964. Defining and Estimating a Trading Area. J. Mark. 28, 34-38.

Huff, D.L., 1963. A Probabilistic Analysis of Shopping Center Trade Areas. Land Econ. 39, 81-90.

Kerkman, K., Martens, K., Meurs, H., 2017. A multilevel spatial interaction model of transit flows incorporating spatial and network autocorrelation. J. Transp. Geogr. 60, 155-166. doi:10.1016/j.jtrangeo.2017.02.016

Malchow, M.B., Kanafani, A., 2001. A disaggregate analysis of factors influencing port selection. Marit. Policy Manag. 28, 265-277. doi:10.1016/j.tre.2003.05.001

Márquez-Ramos, L., 2016. Port facilities, regional spillovers and exports: Empirical evidence from Spain. Pap. Reg. Sci. 95, 199-439. doi:10.1111/pirs.12127

Márquez-Ramos, L., Martínez-Zarzoso, I., Pérez-García, E., Wilmsmeier, G., 2011. Special Issue on Latin-American Research: Maritime Networks, Services Structure and Maritime Trade. Networks Spat. Econ. 11, 555-576.

Martínez Moya, J., Feo Valero, M., 2016. Port choice in container market: a literature review. Transp. Rev. 0, 1-22. doi:10.1080/01441647.2016.1231233

Merkel, A., 2017. Spatial competition and complementarity in European port regions. J. Transp. Geogr. 61, 40-47. doi:10.1016/j.jtrangeo.2017.04.008

Monios, J., 2011. The role of inland terminal development in the hinterland access strategies of Spanish ports. Res. Transp. Econ. 33, 59-66. doi:10.1016/j.retrec.2011.08.007

Nazemzadeh, M., Vanelslander, T., 2015. The container transport system: Selection 
criteria and business attractiveness for North-European ports. Marit. Econ. Logist. 17, 221-245. doi:10.1057/mel.2015.1

Ng, A.K.Y., 2013. The Evolution and Research Trends of Port Geography. Prof. Geogr. 65, 65-86. doi:10.1080/00330124.2012.679441

Ng, A.K.Y., 2006. Assessing the Attractiveness of Ports in the North European Container Transhipment Market: An Agenda for Future Research in Port Competition. Marit. Econ. Logist. 8, 234-250. doi:10.1057/palgrave.mel.9100158

Ng, A.K.Y., Ducruet, C., Jacobs, W., Monios, J., Notteboom, T., Rodrigue, J.P., Slack, B., Tam, K.C., Wilms meier, G., 2014. Port Geography at the crossroads with human geography: between flows and spaces. J. Transp. Geogr. 41, 84-96. doi:10.1016/j.jtrangeo.2014.08.012

Notteboom, T., Rodrigue, J.-P., 2005. Port regionalization: towards a new phase in port development. Marit. Policy Manag. 32, 297-313.

Notteboom, T.E., 2010. Concentration and the formation of multi-port gateway regions in the European container port system: An update. J. Transp. Geogr. 18, 567-583. doi:10.1016/j.jtrangeo.2010.03.003

Notteboom, T.E., 2008. The Relationship between Seaports and the Intermodal Hinterland in light of Global Supply Chains, OECD-ITF Round Table on Seaport Competition and Hinterland Connections. doi:10.1787/9789282102251-en

Notteboom, T.E., Rodrigue, J.-P., 2007. Re-assessing port-hinterland relationships in the context of global supply chains. Ports, Cities, Glob. Supply Chain. 51-66.

Oliveira, G.F. de, Cariou, P., 2015. The impact of competition on container port (in)efficiency. Transp. Res. Part A Policy Pract. 78, 124-133. doi:10.1016/j.tra.2015.04.034

Parola, F., Risitano, M., Ferretti, M., Panetti, E., 2017. The drivers of port competitiveness: A critical review. Transp. Rev. 37, 116-138. doi:10.1080/01441647.2016.1231232

Reilly, W.J., 1929. Methods for the Study of Retail Relationships, Bulletin 2944. University of Texas, Austin, Texas.

Rodrigue, J.-P., 2012. Supply Chain Management, Logistics Changes and the Concept of Friction, in: Hall, P. V, Hesse, M. (Eds.), Cities, Regions and Flows. Routledge, London.

Rodrigue, J.-P., Notteboom, T.E., 2010a. Comparative North American and European gateway logistics: The regionalism of freight distribution. J. Transp. Geogr. 18, 497507. doi:10.1016/j.jtrangeo.2010.03.006

Rodrigue, J.-P., Notteboom, T.E., 2010b. Foreland-based regionalization: Integrating intermediate hubs with port hinterlands. Res. Transp. Econ. 27, 19-29. 
Rodrigue, J.-P., Notteboom, T.E., 2006. Challenges in the Maritime-Land Interface : Port Hinterlands and Regionalization 1-27.

Roy, J.R., 2004. Spatial Interaction Modelling: a Regional Science Context - - Advances in Spatial Science, Springer. doi:10.1007/978-3-642-17940-2

Sanchez, R.J., Ng, A.K.Y., Garcia-Alonso, L., 2011. Port Selection Factors and Attractiveness: The Service Providers' Perspective. Transp. J. 50, 141-161.

Santos, T.A., Soares, C.G., 2017. Development dynamics of the Portuguese range as a multi-port gateway system. J. Transp. Geogr. 60, 178-188. doi:10.1016/j.jtrangeo.2017.03.003

Shi, X., Li, H., 2016. Developing the port hinterland: Different perspectives and their application to Shenzhen Port, China. Res. Transp. Bus. Manag. 19, 42-50. doi:10.1016/j.rtbm.2016.05.004

Stelder, D., 2016. Regional accessibility trends in Europe: Road infrastructure, 19572012. Reg. Stud. 50, 983-995. doi:10.1080/00343404.2014.952721

Stillwell, J., 2005. Inter-regional migration modelling - a review and assessment, in: 45th Congress of the European Regional Science Association.

Tongzon, J.L., 2009. Port choice and freight forwarders. Transp. Res. Part E Logist. Transp. Rev. 45, 186-195. doi:10.1016/j.tre.2008.02.004

van Der Horst, M., De Langen, P.W., 2008. Coordination in Hinterland Transport Chains: A Major Challenge for the Seaport Community. Marit. Econ. Logist. 10, 108-129.

Veldman, S., Garcia-Alonso, L., Vallejo-Pinto, J.Á., 2011. Determinants of container port choice in Spain. Marit. Policy Manag. 38, 509-522.

Wilms meier, G., Monios, J., Pérez-Salas, G., 2014. Port system evolution - the case of Latin America and the Caribbean. J. Transp. Geogr. 39, 208-221. doi:10.1016/j.jtrangeo.2014.07.007

Woo, S.-H., Pettit, S.J., Kwak, D.-W., Beresford, A.K.C., 2011. Seaport research: A structured literature review on methodological issues since the 1980s. Transp. Res. Part A Policy Pract. 45, 667-685. doi:10.1016/j.tra.2011.04.014

Wooldridge, J.M., 2009. Introductory Econometrics: a Modern Approach, Fourth. ed, Journal of contaminant hydrology. Cengage Learning. doi:10.1016/j.jconhyd.2010.08.009

Zeileis, A., 2006. Journal of Statistical Software. J. Stat. Softw. 16, 1-16.

Zeileis, A., 2004. Econometric Computing with HC and HAC Covariance Matrix Estimators. J. Stat. Softw. 11, 1-17. doi:10.18637/jss.v011.i10 
Zhuang, J., Yu, S., 2014. The hinterland spatial structure evolvement of competitive port based on ArcGIS, in: Wen, Z., Li, T. (Eds.), Advances in Intelligent Systems and Computing. Springer Heidelberg New York Dordrecht London, pp. 1143-1153. doi:10.1007/978-3-642-54927-4 